\title{
A Single Monoclonal Antibody against the Peanut Allergen Ara h 2 Protects against Systemic and Local Peanut Allergy
}

\author{
Federico Storni ${ }^{a, b, g}$ Gustavo Cabral-Miranda ${ }^{a, b}$ Elisa Roesti ${ }^{a, b}$ Lisha Zha ${ }^{c}$ \\ Paul Engeroff ${ }^{a, b}$ Andris Zeltins ${ }^{e}$ Mark Cragg $^{f}$ Monique Vogel $^{a, b}$ \\ Martin F. Bachmann ${ }^{a, b}, d$ \\ a Immunology, RIA, Inselspital, University of Bern, Bern, Switzerland; b Department of BioMedical Research, \\ University of Bern, Bern, Switzerland; 'International Immunology Center of Anhui Agricultural Center, Anhui, China; \\ dNuffield Department of Medicine, Centre for Cellular and Molecular Physiology (CCMP), The Jenner Institute,

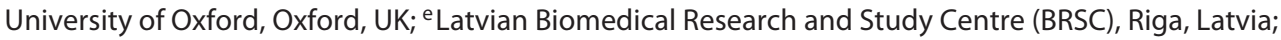 \\ ${ }_{\mathrm{f}}$ Antibody and Vaccine Group, Centre for Cancer Immunology, Cancer Sciences Unit, Faculty of Medicine, \\ General Hospital, University of Southampton, Southampton, UK; ${ }^{9}$ Department of Visceral Surgery and Medicine, \\ University Hospital of Bern, Bern, Switzerland
}

\section{Keywords}

Food allergy · Antibody therapy · FcyRIlb dependency

\begin{abstract}
Background: Peanut allergy is the most prevalent and dangerous food allergy. Peanuts consist of a large number of different allergens and peanut-allergic patients are frequently sensitized to multiple allergens. Hence, conventional desensitization approaches aim at targeting as many allergens as possible. Methods: The monoclonal anti-Ara h 2 antibody (mAb) was produced by hybridoma cells derived from WT $B A L B / c$ mice after immunization with a vaccine based on virus-like particles coupled to Ara h 2. BALB/c mice were sensitized intraperitoneally with peanut extract absorbed to alum and mAbs were applied i.v. Challenge was performed the next day with the whole peanut extract intravenously and via skin prick test. Results: Here we show in peanut-allergic mice that a single high-affinity mAb specific for Ara $\mathrm{h} 2$ is able to
\end{abstract}

\begin{tabular}{ll}
\hline KARGER & (c) 2020 The Author(s) \\
Published by S. Karger AG, Basel & This article is licensed under the Creative Commons Attribution- \\
karger@karger.com & NonCommercial-NoDerivatives 4.0 International License (CC BY- \\
NC-ND) (http://www.karger.com/Services/OpenAccessLicense). \\
Usww.karger.com/iaa \\
tribution of modified material requires written permission.
\end{tabular}

block systemic and local allergic reactions induced by the complex peanut extract. We confirm in vitro binding of the $\mathrm{mAb}$ to the inhibitory low-affinity FcyRllb receptor using a sensitive biosensor and demonstrate in vivo that protection was dependent on FcyRIlb. Conclusion: A single mAb specific for Ara $\mathrm{h} 2$ is able to improve local and systemic allergic symptoms induced by the whole allergen mixture.

(c) 2020 The Author(s)
Published by S. Karger AG, Basel

\section{Introduction}

Peanut allergy is a frequent disease in Western countries with an increasing prevalence currently ranging between 1.4 and 3\% in children [1]. The disease typically develops early in life and is rarely outgrown with

Edited by: H.-U. Simon, Bern.
Dr. Federico Storni

Immunology, RIA, Inselspital, University of Bern Sahlihaus $1 / 2$

CH-3010 Bern (Switzerland)

federico.storni@insel.ch 
age [2]. Peanut allergy is a frequent cause of anaphylactic reactions and death among food allergies and hence a severe disease. As peanut is used in a vast number of different food products, exposure is largely unpredictable. The psychosocial and economic consequences are therefore of major importance [3]. Peanuts contain up to $30 \%$ of allergenic proteins [4], there are at least 16 allergens described (Ara h nomenclature) [5]. As immunotherapy (SIT) is typically thought to be allergen-specific, the preferred therapeutic concept is the use of allergen extracts for SIT to target all possible allergens. Efficacy and safety of this approach may be enhanced by using allergoids [6] or displaying allergens on virus-like particles [7] and optimizing the use of adjuvants [8]. Nevertheless, the use and standardization of allergen extracts is complex and immunogenicity/efficacy remains limited. While the exact mechanism of how SIT reduces allergic symptoms is still under debate, it has recently been shown that monoclonal antibodies (mAbs) against Fel d 1, the major and essentially only clinically relevant allergen in cats, can dramatically improve symptoms of allergy in mice [9] and humans [10]. However, it remains unclear whether targeting complex allergen mixtures by mAbs is also a feasible therapeutic approach.

\section{Materials and Methods}

Production of Peanut Extract and Ara h 2

The production of roasted peanut extract and Ara $\mathrm{h} 2$ including the protein characterization on SDS-Page are described in Storni et al. [J Allergy Clin Immunol, 2020, in press].

Generation of CuMVtt-Ara h 2 and Ara h 2 Specific Antibodies

Mice were immunized with recombinant Ara h 2 coupled to virus-like particles derived from cucumber mosaic virus [Storni et al., J Allergy Clin Immunol, 2020, in press]. WT BALB/c mice were immunized four times with CuMVtt-Ara h 2 (twice s.c. and twice i.v., with an interval of 2 weeks) and $\mathrm{mAb}$ was generated according to standard protocols [11].

ELISA for Determining the Isotype Subclass of mAbs Anti-Ara $h 2$ and Binding to Ara h 2, Peanut Extract, Ara h 1, and Ara h 6

96-well Nunc Maxisorp ${ }^{\mathrm{TM}}$ ELISA plates (Thermo Fisher Scientific, Waltham, MA, USA) were coated with $1 \mu \mathrm{g} / \mathrm{mL}$ Ara h 2 in carbonate buffer at $4{ }^{\circ} \mathrm{C}$ overnight. After blocking with $\mathrm{PBS} / 0.15 \%$ casein solution for $2 \mathrm{~h}$, plates were washed five times with $\mathrm{PBS} / 0.05 \%$ Tween. Serial dilutions of $\mathrm{mAbs}$ anti-Ara $\mathrm{h} 2$ were added to the plates and incubated for $2 \mathrm{~h}$ at $4{ }^{\circ} \mathrm{C}$. Plates were then washed five times with PBS/0.05\% Tween. For determination of peanut extract specific IgG subclasses, biotin-labeled mouse antimouse IgG1 (The Jackson Laboratory, Bar Harbor, ME, USA), bi- otin-labeled mouse anti-mouse IgG2a (Becton Dickinson, Franklin Lakes, NJ, USA), or biotin-labeled rat anti-mouse IgG2b (BioLegend, San Diego, CA, USA) were used as detection antibodies for $1 \mathrm{~h}$ at $4^{\circ} \mathrm{C}$. Thereafter, HRP-labeled streptavidin (DakoCytomation, Denmark) was incubated at $4^{\circ} \mathrm{C}$ for $1 \mathrm{~h}$. To determine the binding or cross-reactivity of anti-Ara h 2 IgG to peanut extract, Ara h 2, Ara h 1, or Ara h 6, ELISA plates were coated with the corresponding antigen in a concentration of $2 \mu \mathrm{g} / \mathrm{mL}$ in carbonate buffer at $4{ }^{\circ} \mathrm{C}$ overnight. Serial dilutions of IgG anti-Ara h 2 were added to the plates and incubated for $2 \mathrm{~h}$ at $4^{\circ} \mathrm{C}$. Plates were then washed five times with PBS/0.05\% Tween. Thereafter, HRP-labeled goat anti-mouse IgG (The Jackson Laboratory, Bar Harbor, ME, USA) antibodies were incubated at $4{ }^{\circ} \mathrm{C}$ for $1 \mathrm{~h}$. ELISAs were developed with $\operatorname{TMB}(3,30,5,50$-tetramethyl-benzidine $)$ and $\mathrm{H}_{2} \mathrm{O}_{2}$ and stopped with $1 \mathrm{~mol} / \mathrm{L}$ sulfuric acid. Optical densities were measured at $450 \mathrm{~nm}$.

Dot Blot to Determine Binding of Anti-Ara $h 2$ IgG to

Recombinant Ara $h 2$ and Peanut Extract

To confirm binding of anti-Ara h 2 IgG to Ara h 2 and peanut extract, serial dilutions of Ara h 2 or peanut extract were applied on a nitrocellulose membrane. The membrane was boiled for 5 min at $900 \mathrm{~W}$ in a $4.3 \mathrm{mM} \mathrm{Na}_{2} \mathrm{HPO}_{4} 1.4 \mathrm{mM} \mathrm{KH}_{2} \mathrm{PO}_{4}$ containing buffer to expose epitopes and increase antigen binding. Thereafter, the membrane was washed twice with PBS/0.05\% Tween and once in PBS and blocked in a $50 \mathrm{~mm}$ Tris-buffer containing $0.1 \%$ Tween 20 and $2.5 \%$ casein for $1 \mathrm{~h}$ at room temperature. The membrane was further incubated with anti-Ara h 2 IgG $10 \mu \mathrm{g} / \mathrm{mL}$ for 2 $\mathrm{h}$ at room temperature. After washing, the membrane was incubated with goat anti-mouse IgG conjugated with horse-radish peroxidase (Jackson ImmunoResearch Laboratories, USA) for $1 \mathrm{~h}$ at room temperature. The membrane was developed with Thermo Scientific ${ }^{\mathrm{TM}}$ SuperSignal ${ }^{\mathrm{TM}}$ West Femto (Thermo Fisher Scientific, Waltham, MA, USA) and pictures were acquired with an Azure C300 Imaging System (Axon Lab AG, Switzerland).

\section{Binding of mAb Anti-Ara h 2 to FcyRIIb and Generation of} Biosensor

Biosensor Apparatus

The electrochemical measurements were performed with a Metrohm Autolab, PGSTAT320N, potentiostat/galvanostat, controlled by NOVA 1.11 software. The carbon screen printed electrodes (carbon-SPEs) were of commercial origin (Orion, Madrid, Spain) - any other carbon-SPEs may be applied herein. The threeelectrode system of the carbon-SPEs contained (i) a counter electrode made of carbon, (ii) a reference electrode made of silver, and (iii) a carbon working electrode of $4 \mathrm{~mm}$ diameter. All electrical connections were made of silver. The carbon-SPEs were interfaced with the potentiostat by means of a switch box (BioTID, Portugal).

Synthesis of the Sensing Layer

The system used to build this biosensor is similar to the one previously described [12]. Following the previous biosensor delineation, we applied Fc $\gamma$ RIIb probes to make a bio-interface with carbon-SPEs (from Orion). Antibody and immune complex binding was made by casting standard solutions of mAb anti-Ara h 2 or mixed equimolarly with Ara h 2. Each standard was incubated for $30 \mathrm{~min}$ at $37^{\circ} \mathrm{C}$. The positive serum samples were tested similarly using anti-Fc $\gamma$ RIIb antibodies. 
Electrochemical Procedures

The electrochemical studies of electrochemical impedance spectroscopy (EIS) were performed in the iron redox probe solution as described [12]. To analyze EIS data, Nyquist plots were used to plot the obtained spectra, showing the frequency response of the electrolyte system and plotting the imaginary component $\left(Z^{\prime \prime}\right)$ of the impedance against its real component $\left(Z^{\prime}\right)$. EIS data was fitted herein into the typical Randle's equivalent circuit, which matched the physiochemical processes occurring at the carbon electrode surface [12].

\section{Mice Challenge Experiments}

Female WT BALB/c mice (Envigo, Huntingdon, UK) were purchased at the age of 6 weeks and kept at the DBMR animal facility, Murtenstrasse 31, Bern. All animals were used for experimentation according to protocols approved by the Swiss Federal Veterinary Office (license BE 70/18).

Seven- to eight-week-old naïve $\mathrm{BALB} / \mathrm{c}$ mice were sensitized to peanut by injecting i.p. at day 0 and day 7 with $5 \mu \mathrm{g}$ roasted peanut extract mixed in $200 \mu \mathrm{L}$ alum $\left(10 \mathrm{mg} / \mathrm{mL} \mathrm{Al}(\mathrm{OH})_{3}\right.$; Alhydrogel; InvivoGen, USA).

For the induction of anaphylaxis, sensitized mice were challenged i.v. with $20 \mu \mathrm{g}$ roasted peanut extract in $200 \mu \mathrm{L}$ PBS 2 weeks after sensitization. Temperature was measured with a rectal probe thermometer (Vetronic Services LTD, Devon, UK) before i.v. antigen challenge and monitored for $50 \mathrm{~min}$ after challenge every 10 min.

The local anaphylaxis was assessed by ear prick test. Mice were injected i.v. with $200 \mu \mathrm{L}$ of Evans blue solution (0.5\% in PBS). Afterwards, a drop of peanut extract solution $(180 \mu \mathrm{g} / 20 \mu \mathrm{L}$ PBS $)$ was placed onto the outer ear skin of anesthetized mice. Pricks on the ear skin were performed with $23-\mathrm{G}(0.6 \mathrm{~mm} \AA \sim 25 \mathrm{~mm})$ needles (Microlance, BD, USA). To assess Fc $\gamma$ RIIb receptor function, designed ankyrin repeat proteins (DARPins, described in Zellweger et al. [13]) against mouse Fc $\gamma$ RIIb receptor were used for blocking the receptor by means of local subcutaneous injection on the ears 10 min before the ear prick. Dye extravasations started immediately after antigen challenge. Forty minutes later, mice were sacrificed and ears were collected and imaged with an Azure C300 Imaging System (Axon Lab AG, Switzerland). Surface of the blue extravasation was quantified by Fiji Image J software.

To investigate the effect of anti-Ara h $2 \mathrm{IgG}, 200 \mu \mathrm{g}$ of mAbs were injected i.v. in $200 \mu \mathrm{L}$ PBS $24 \mathrm{~h}$ before challenge with the whole peanut extract. Control mice were injected with $200 \mu \mathrm{g}$ of murine monoclonal anti-Fel d $1 \mathrm{IgG}$. Challenge was performed i.v. or via skin prick test.

To assess Fc $\gamma$ RIIb receptor function, designed ankyrin repeat proteins (DARPins) [13] against mouse Fc $\gamma$ RIIb receptor were used for blocking the receptor by means of local subcutaneous injection on the ears 10 min before the ear prick. To assess the role of the inhibitory Fc $\gamma$ RIIb receptor on basophils and mast cells on a systemic level, mice were injected i.v. with $150 \mu \mathrm{g}$ anti-Fc $\gamma \mathrm{RIIb}$ antibody (AT128) 24 h before i.v. challenge with peanut extract. As a control isotype antibody, $150 \mu \mathrm{g}$ anti-histidine antibodies were injected in control mice.

\section{Statistical Analysis}

Statistical tests were performed with GraphPad PRISM 6.0 (Graph-Pad Software, Inc., La Jolla, CA, USA). Statistical significance is displayed as $p \leq 0.05\left(^{*}\right), p \leq 0.01\left(^{* *}\right), p \leq 0.001\left(^{* * *}\right)$, $\left.p \leq 0.0001{ }^{(* * * *}\right)$. Groups for dot surface after skin prick test were analyzed by unpaired two-tailed Student's $t$ test. Anaphylaxis curves were analyzed by repeated measures two-way ANOVA test.

\section{Results}

\section{Monoclonal IgG Anti-Ara $\mathrm{h} 2$ Binds to Recombinant}

Ara $h 2$ and Peanut Extract

The monoclonal IgG anti-Ara h 2 was generated according to standard procedures upon immunization of mice with Ara h 2 coupled to CuMVtt [Storni et al., J Allergy Clin Immunol, 2020, in press]. As shown in Figure $1 \mathrm{a}$, the antibody isotype is IgG2a, while the antibody has specificity for Ara $\mathrm{h} 2$ and peanut extract as demonstrated by ELISA (Fig. 1b) and dot blot (Fig. 1c). Cross-reactivity of this mAb to Ara h 1 and Ara h 6 was low. Therefore, we attribute the main effect of $\mathrm{mAb}$ anti-Ara $\mathrm{h} 2$ in vivo described below to Ara h 2 specificity and not to crossreactivity to other peanut allergens.

\section{mAb Anti-Ara $h 2$ Binds to Murine Fc $\gamma$ RIIb}

Affinities of IgG antibodies to the Fc $\gamma$ RIIb are low in general even if immune-complexed to allergen and these interactions are therefore very hard to measure. To be able to measure specific interaction between $\mathrm{Fc} \gamma \mathrm{RIIb}$ and $\mathrm{mAb}$ anti-Ara h 2, we employed a highly sensitive biosensor previously described for measurement of antibodies directed against Plasmodium falciparum and Zika virus [12]. To this end, recombinant murine Fc $\gamma$ RIIb was coated on a carbon-SPE before incubation with $\mathrm{mAb}$ anti-Ara h 2 in free form or immune-complexed with Ara h 2.

We have previously shown that binding of ligands to carbon-nanotube bound protein changes the electric properties, causing changes in electrical impedance, which was used as a read-out for protein binding as described earlier $[14,15]$. As shown in Figure $2 a$ and b, mAb anti-Ara $\mathrm{h} 2$ bound in free and in immune-complexed form to recombinant F $c \gamma$ RIIb. However, the binding of immune-complexed anti-Ara h 2 to Fc $\gamma$ RIIb was stronger than to free anti-Ara $\mathrm{h} 2$, in line with previous findings showing that immune complexes bind Fc $\gamma$ RIIb more effectively than free $\mathrm{mAb}$.

\section{IgG Anti-Ara h 2 Protects against Anaphylaxis}

To investigate the protective potential of IgG anti-Ara h 2 against anaphylaxis, sensitized BALB/c mice were injected i.v. with mAbs anti-Ara h 24 h before i.v. or skin prick challenge. Injection of $200 \mu \mathrm{g}$ mAbs anti-Ara h 2 into peanut-sensitized mice protected from anaphylactic reactions (Fig. 3a). 


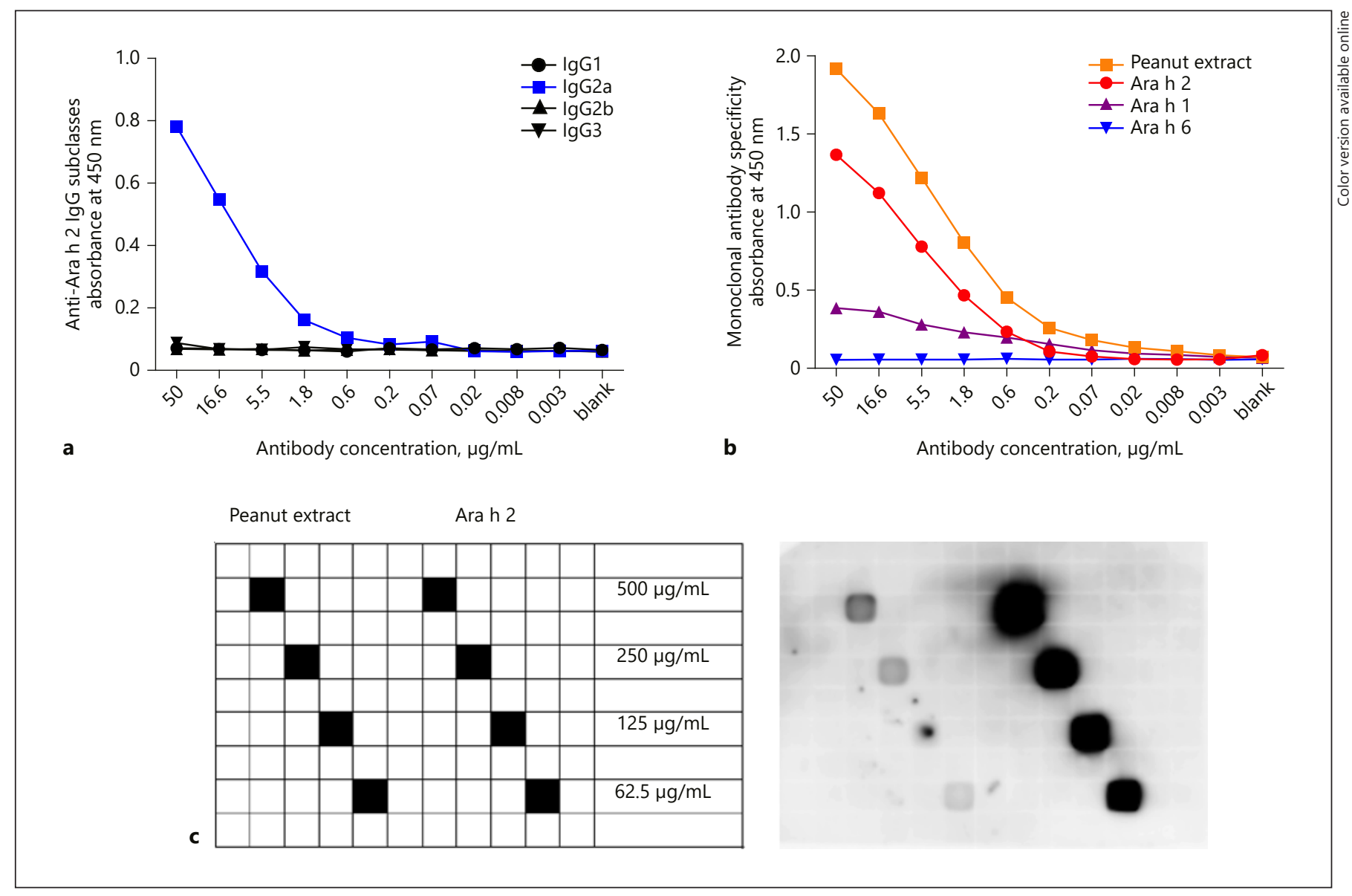

Fig. 1. Monoclonal IgG anti-Ara h 2 binds to recombinant Ara h 2 and peanut extract. ELISA was performed to detect the IgG subclass of monoclonal anti-Ara h $2 \operatorname{IgG}(\mathbf{a})$ and the specificity to peanut extract (in orange), Ara h 2 (in red), Ara h 1 (in purple), and Ara h 6 (in blue) (b). c Dot blot confirms binding of monoclonal IgG antiAra h 2 to Ara h 2 (on the right side of the membrane) and peanut extract (on the left side of the membrane).

\section{IgG Anti-Ara h 2 Diminishes Local Reaction after Challenge via Skin Prick Test}

To examine the effect of IgG anti-Ara h 2 on local allergic reactions, skin prick tests were performed in peanut-sensitized mice injected with $\mathrm{mAbs}$ or monoclonal anti-Fel $\mathrm{d} 1$ antibody, as control. In order to visualize extravasation, mice were pretreated i.v. with Evans blue [11]. Allergen challenge by pricking into the ear skin with peanut extract induced vascular leakage in control mice. In contrast, animals pretreated with IgG anti-Ara $\mathrm{h} 2$ showed significantly smaller extravasation surface (Fig. 3b).

\section{The Inhibitory FcyRIIb Receptor Is Required for}

Protection Induced by Anti-Ara h 2 IgG

To investigate whether the inhibitory $\mathrm{Fc} \gamma \mathrm{RIIb}$ receptor present on mast cells and basophils is involved in the protection induced by IgG antibodies generated after anti-Ara h 2 injection, peanut-sensitized BALB/c mice were challenged i.v. $24 \mathrm{~h}$ after injection of an anti-Fc $\gamma \mathrm{RIIb}$ $\mathrm{mAb}$ (AT 128) to block the Fc $\gamma \mathrm{RIIb}$ receptor or a control murine IgG. As shown in Figure 3c, the protection conferred by passive vaccination with $\mathrm{mAbs}$ IgG anti-Ara $h$ 2 was abrogated by systemic injection of Fc $\gamma$ RIIb-blocking antibody. Protection was not affected when mice were injected with isotype control IgG.

The involvement of the inhibitory receptor Fc $\gamma$ RIIb in protection was confirmed via skin prick test after locally blocking the $\mathrm{Fc} \gamma \mathrm{RIIb}$ receptor with an inhibitor molecule (based on DARPin technology) specific to FcyRIIb [16]. As shown above, anti-Ara h 2 IgG-treated mice developed much smaller extravasation spots after ear skin prick test, but protection was abrogated by local co-injection of Fc $\gamma$ RIIb-blocking DARPin. Mice with blocked Fc $\gamma$ RIIb 

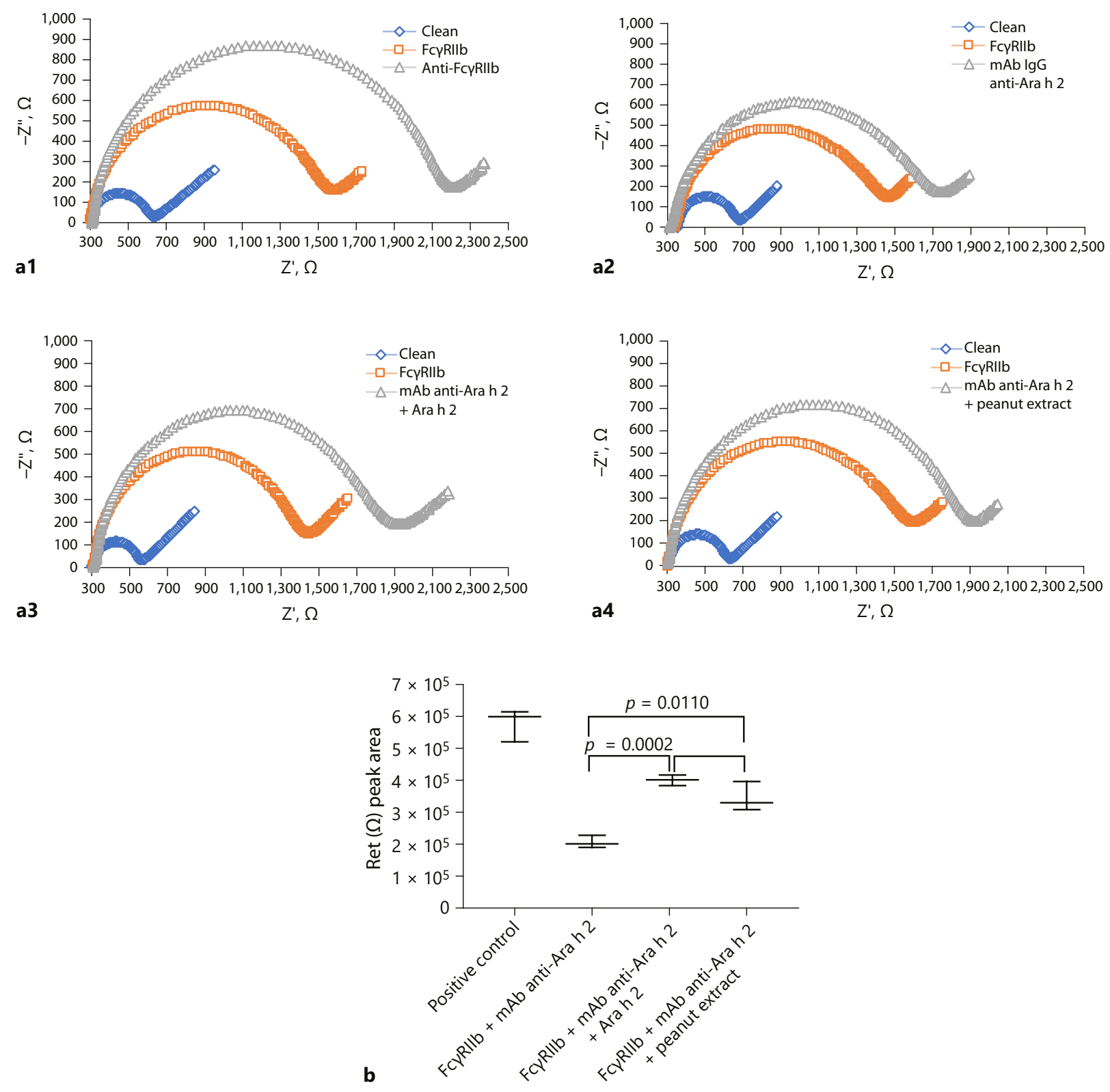

Fig. 2. Binding of monoclonal IgG anti-Ara h 2 to Fc $\gamma$ RIIb. a Measured electrical impedance of positive control anti-Fc $\gamma$ RIIb (a1), $\mathrm{mAb}$ IgG anti-Ara h 2 alone (a2), mAb IgG anti-Ara h 2 in complex with Ara h 2 (a3), and mAb IgG anti-Ara h 2 in complex with peanut extract (a4) (displayed in grey). Carbon screen printed

showed a comparable leakage to allergen-challenged mice without prior exposure to $\mathrm{mAbs}$, demonstrating that inhibitory receptor Fc $\gamma$ RIIb is required for protection (Fig. 3b). electrode background is represented in blue (a1-a4), Fc $\gamma$ RIIb alone is displayed in orange (a1-a4), and Fc $\gamma$ RIIb bind to $\mathrm{mAb}$ Ara $\mathrm{h} 2$ is represented in grey (a2). $\mathbf{b}$ Quantification of the measurement depicted in $\mathbf{a}$.

\section{Discussion/Conclusion}

The goal of immunotherapy in allergic patients is to induce tolerance or reduced responsiveness to the allergen. Efficacy of oral immunotherapy in peanut-allergic 


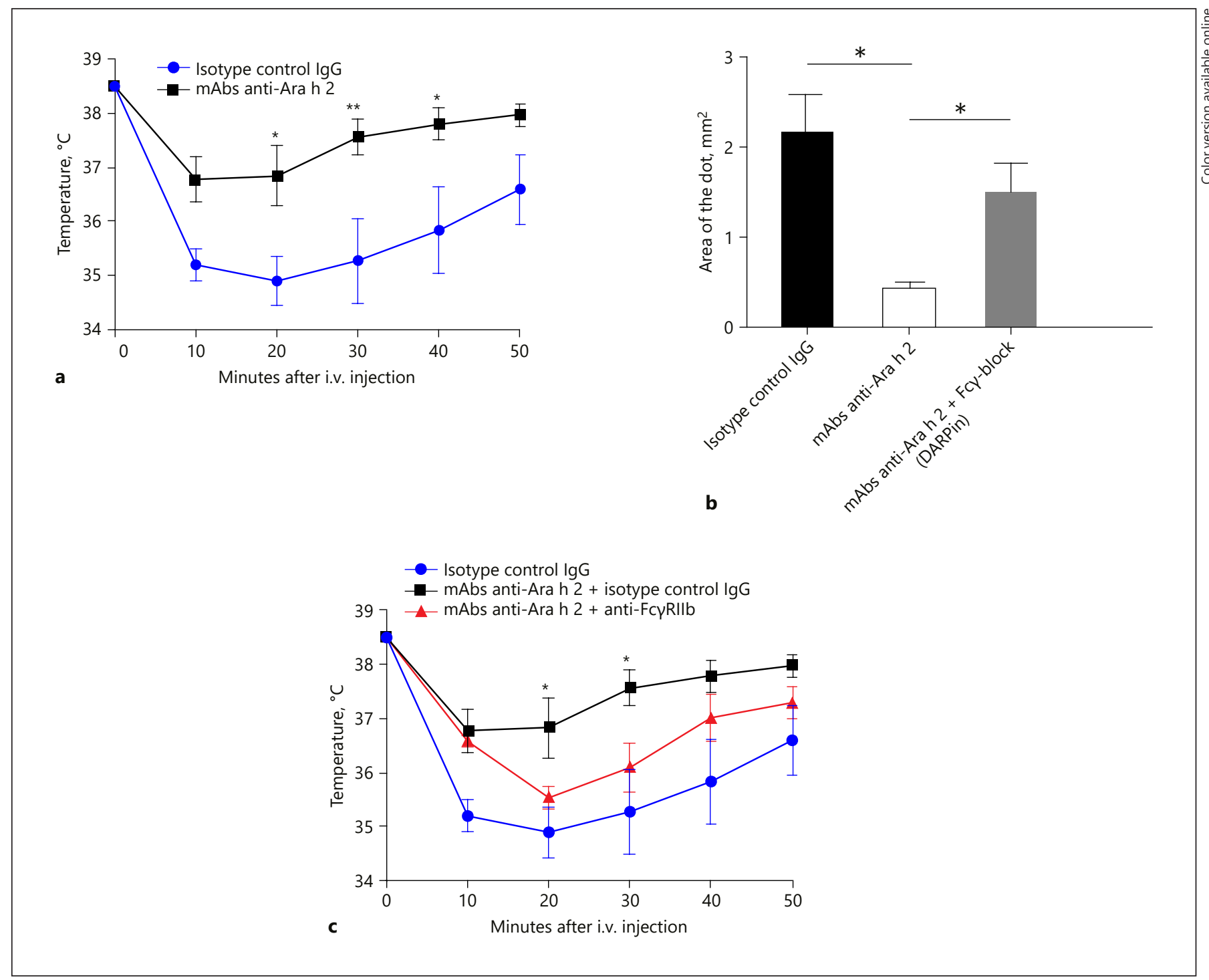

Fig. 3. Monoclonal IgG anti-Ara h 2 protects against systemic and local peanut allergy in a Fc $\gamma$ RIIb-dependent manner. a Temperature after i.v. challenge with peanut extract of peanut-sensitized mice to assess anaphylaxis was measured rectally every $10 \mathrm{~min}$ for $50 \mathrm{~min}$. Mice were pretreated $24 \mathrm{~h}$ before challenge with monoclonal IgG anti-Ara h 2 or an isotype control IgG. b Effect of IgG anti-Ara $\mathrm{h} 2$ and involvement of Fc $\gamma$ RIIb was addressed on a local level via skin prick test. Fc $\gamma$ RIIb was locally blocked with DARPin.

patients was demonstrated in a phase 3 clinical trial for children and adolescents [17]. In recent studies, induction of regulatory T cells [18] or a shift from Th2 to Th1 [19] were discussed as possible mechanisms underlying induction of tolerance. The central role of allergen-specific IgGs in allergy protection was recently strikingly demonstrated in a clinical study with anti-Feld d $1 \mathrm{mAbs}$
Means \pm SEM are shown ( $n=3$ mice per group, data are representative of 3 independent experiments). Statistical significance was analyzed by two-tailed $t$ test. c To address Fc $\gamma$ RIIb involvement in protection, mice received $150 \mu \mathrm{g}$ of anti-Fc $\gamma \mathrm{RIIb}$ or an isotype control IgG $24 \mathrm{~h}$ before challenge. Means \pm SEM are shown $(n=4$ to 5 mice per group). Data are representative of 3 independent experiments. Statistical significance was analyzed by two-way ANOVA test.

[10]. Here we extend these findings from a single allergen-disease (sensitization to Fel d 1) to complex allergen mixtures and demonstrate in mice that targeting the single major allergen Ara h 2 in a complex allergen mixture is sufficient to control disease symptoms upon local and systemic allergen challenge. This finding is consistent with previous studies demonstrating successful immuno- 
therapy based on one allergen in polysensitized patients [20]. The present experiments extend these findings to show that a single $\mathrm{mAb}$ specific for a single allergen may be able to cause similar protection. Our study may present a limitation concerning the animal model (intraperitoneal way of sensitization and intravenous allergen challenge, both not physiologic for peanut allergy in humans). Nevertheless, parenteral allergen injection may reproduce a systemic allergen exposure as previously shown [21]. Further studies including experiments with different $\mathrm{mAbs}$ presenting distinct specificities are needed to support this novel concept. Potential clinical applications of protective mAbs against allergy are imaginable especially in prophylactic settings in severely allergic patients at risk for anaphylactic shock.

\section{Acknowledgement}

We thank our colleagues from Latvian Biomedical Research and Study Centre (BRSC), Riga, Latvia, Gunta Reseviča, Vilija Zeltina, and Janis Bogans for elaboration of protocols for peanut allergen purification.

\section{Statement of Ethics}

All animals were used for experimentation according to protocols approved by the Swiss Federal Veterinary Office (license BE 70/18).

\section{Disclosure Statement}

M.F.B. declares to be involved in a number of companies developing VLP-based vaccines. The other authors declare no further conflict of interest.

\section{Funding Sources}

This study was funded by the Swiss National Science Foundation (SNF grant 31003A 149925) to M.F.B.

\section{Author Contributions}

F.S., G.C.-M., L.Z., E.R., P.E., L.M. C.M. performed experiments and interpreted data. F.S. and M.F.B. designed the study. F.S., M.V., and M.F.B wrote the manuscript.

\section{References}

1 Nwaru BI, Hickstein L, Panesar SS, Muraro A, Werfel T, Cardona V, et al.; EAACI Food Allergy and Anaphylaxis Guidelines Group. The epidemiology of food allergy in Europe: a systematic review and meta-analysis [Internet]. Allergy. 2014 Jan;69(1):62-75. [cited 2018 Apr 10] Available from: http://doi.wiley. com/10.1111/all.12305

2 Fleischer DM, Conover-Walker MK, Christie L, Burks AW, Wood RA. The natural progression of peanut allergy: resolution and the possibility of recurrence [Internet]. J Allergy Clin Immunol. 2003 Jul;112(1):183-9. [cited 2018 Apr 11] Available from: http://www.ncbi. nlm.nih.gov/pubmed/12847497

3 Cummings AJ, Knibb RC, King RM, Lucas JS. The psychosocial impact of food allergy and food hypersensitivity in children, adolescents and their families: a review [Internet]. Allergy. 2010 Aug;65(8):933-45. [cited 2018 Apr 11] Available from: http://doi.wiley.com/ 10.1111/j.1398-9995.2010.02342.x

4 Koppelman SJ, Vlooswijk RA, Knippels LM, Hessing M, Knol EF, van Reijsen FC, et al. Quantification of major peanut allergens Ara $\mathrm{h} 1$ and Ara $\mathrm{h} 2$ in the peanut varieties Runner, Spanish, Virginia, and Valencia, bred in different parts of the world [Internet]. Allergy. 2001 Feb;56(2):132-7. [cited 2019 Sep 17] Available from: http://www.ncbi.nlm.nih. gov/pubmed/11167373
5 Palladino C, Breiteneder H. Peanut allergens [Internet]. Mol Immunol. 2018 Aug;100:5870. [cited 2019 Sep 17] Available from: https:// www.sciencedirect.com/science/article/pii/ S0161589018301226?via\%3Dihub

6 Berings M, Karaaslan C, Altunbulakli C, Gevaert $P$, Akdis $M$, Bachert $C$, et al. Advances and highlights in allergen immunotherapy: on the way to sustained clinical and immunologic tolerance [Internet]. J Allergy Clin Immunol. 2017 Nov;140(5):1250-67. [cited 2019 Dec 13] Available from: http://www. ncbi.nlm.nih.gov/pubmed/28941667

7 Engeroff P, Caviezel F, Storni F, Thoms F, Vogel M, Bachmann MF. Allergens displayed on virus-like particles are highly immunogenic but fail to activate human mast cells [Internet]. Allergy. 2018 Feb;73(2):341-9. [cited 2018 Mar 21] Available from: http://doi.wiley. com/10.1111/all.13268

8 Leuthard DS, Duda A, Freiberger SN, Weiss S, Dommann I, Fenini G, et al. Microcrystalline Tyrosine and Aluminum as Adjuvants in Allergen-Specific Immunotherapy Protect from IgE-Mediated Reactivity in Mouse Models and Act Independently of Inflammasome and TLR Signaling [Internet]. J Immunol. 2018 May;200(9):3151-9. [cited 2019 Sep 17] Available from: http://www.ncbi.nlm.nih. gov/pubmed/29592962
9 Uermösi C, Beerli RR, Bauer M, Manolova V, Dietmeier K, Buser RB, et al. Mechanisms of allergen-specific desensitization [Internet]. J Allergy Clin Immunol. 2010 Aug;126(2):37583. [cited 2019 Sep 17] Available from: http:// www.ncbi.nlm.nih.gov/pubmed/20624641

10 Orengo JM, Radin AR, Kamat V, Badithe A, Ben LH, Bennett BL, et al. Treating cat allergy with monoclonal IgG antibodies that bind allergen and prevent IgE engagement [Internet]. Nat Commun. 2018 Apr;9(1):1421. [cited 2018 May 8] Available from: http://www. nature.com/articles/s41467-018-03636-8

11 Evans H, Killoran KE, Mitre E. Measuring local anaphylaxis in mice [Internet]. J Vis Exp. 2014 Oct;e52005(92):e52005. [cited 2019 Dec 10] Available from: http://www.ncbi.nlm.nih. gov/pubmed/25350839

12 Cabral-Miranda G, de Jesus JR, Oliveira PR, Britto GS, Pontes-de-Carvalho LC, Dutra RF, et al. Detection of parasite antigens in Leishmania infantum-infected spleen tissue by monoclonal antibody-, piezoelectric-based immunosensors [Internet]. J Parasitol. 2014 Feb;100(1):73-8. [cited 2019 Sep 17] Available from: http://www. ncbi.nlm.nih.gov/pubmed/24147835

13 Zellweger F, Gasser P, Brigger D, Buschor P, Vogel M, Eggel A. A novel bispecific DARPin targeting Fc $\gamma$ RIIB and FceRI-bound IgE inhibits allergic responses [Internet]. Allergy. 2017 Aug;72(8):1174-83. [cited 2018 Oct 10] Availablefrom:http://doi.wiley.com/10.1111/ all.13109 
14 Cabral-Miranda G, Cardoso AR, Ferreira LC, Sales MG, Bachmann MF. Biosensor-based selective detection of Zika virus specific antibodies in infected individuals [Internet]. Biosens Bioelectron. 2018 Aug;113:101-7. [cited 2019 Sep 17] Available from: https://linkinghub.elsevier.com/retrieve/pii/S0956566318303270

15 Cardoso AR, Cabral-Miranda G, Reyes-Sandoval A, Bachmann MF, Sales MG. Detecting circulating antibodies by controlled surface modification with specific target proteins: application to malaria [Internet]. Biosens Bioelectron. 2017 May;91:833-41. [cited 2019 Sep 17] Available from: https://linkinghub.elsevier.com/retrieve/pii/S0956566317300313

16 Zha L, Leoratti FM, He L, Mohsen MO, Cragg $\mathrm{M}$, Storni F, et al. An unexpected protective role of low-affinity allergen-specific IgG through the inhibitory receptor Fc $\gamma$ RIIb [Internet]. J Allergy Clin Immunol. 2018 Nov;142(5):1529- 1536.e6. [cited 2018 Apr 17] Available from: https://www.sciencedirect.com/science/article/pii/S009167491830037X?via\%3Dihub

17 PALISADE Group of Clinical Investigators. AR101 Oral Immunotherapy for Peanut Allergy [Internet]. N Engl J Med. 2018 Nov 22; 379(21):1991-2001. [cited 2018 Nov 20]. Available from: http://www.nejm.org/doi/ 10.1056/NEJMoa1812856

18 Böhm L, Maxeiner J, Meyer-Martin H, Reuter S, Finotto S, Klein M, et al. IL-10 and regulatory $\mathrm{T}$ cells cooperate in allergen-specific immunotherapy to ameliorate allergic asthma [Internet]. J Immunol. 2015 Feb;194(3):88797. [cited 2019 Dec 4] Available from: http:// www.ncbi.nlm.nih.gov/pubmed/25527785

19 Kappen JH, Durham SR, Veen HI, Shamji $\mathrm{MH}$. Applications and mechanisms of immunotherapy in allergic rhinitis and asthma [Internet]. Ther Adv Respir Dis. 2017 Jan;11(1):
73-86. [cited 2019 Dec 4] Available from: http://journals.sagepub.com/doi/10.1177/ 1753465816669662

20 Calderón MA, Cox L, Casale TB, Moingeon P, Demoly P. Multiple-allergen and single-allergen immunotherapy strategies in polysensitized patients: looking at the published evidence [Internet]. J Allergy Clin Immunol. 2012 Apr;129(4):929-34. [cited 2019 Dec 4] Available from: https://linkinghub.elsevier. com/retrieve/pii/S0091674911022512

21 Schmitz N, Dietmeier K, Bauer M, Maudrich $M$, Utzinger S, Muntwiler S, et al. Displaying Fel d1 on virus-like particles prevents reactogenicity despite greatly enhanced immunogenicity: a novel therapy for cat allergy [Internet]. J Exp Med. 2009 Aug; 206(9):1941-55. [cited 2016 Apr 11] Available from: http://jem.rupress.org/content/ 206/9/1941.long 